\title{
MULTIBIT STRUCTURE FOR THE FORMATION OF COMBINED OR ALTERNATING ELECTRON-ION BEAMS
}

pages $147-156$

DOI: 10.1615/HighTempMatProc.2020033966

\section{Antonovich}

Polotsk State University, 29 Blokhin Str., Novopolotsk, 211440, Belarus; Vitebsk State University named after P.M. Masherov, 33 Moskovskiy Ave., Vitebsk, 210038, Belarus

\section{Gruzdev}

Polotsk State University, 29 Blokhin Str., Novopolotsk, 211440, Belarus

\section{Zalesski}

Physical-Technical Institute, National Academy of Sciences of Belarus, 10 Academician Kuprevich Str., Minsk, 220141, Belarus

\section{Pavel Soldatenko}

Polotsk State University, 29 Blokhin Str., Novopolotsk, 211440, Belarus

\begin{abstract}
Currently, sources of ion and electron beams make it possible to implement a wide range of effective technologies for processing materials and surface modifications. In some cases, a significant increase in the effectiveness of such technologies is achieved with simultaneous exposure to electron and ion beams through the use of two types of separate (electron and ion) sources. At the same time, experience in the development and use of plasma sources of charged particles shows the possibility of creating a combined electron-ion flow in one direction and in a single discharge system. In this work, we propose an experimental electrode structure of a plasma electron-ion source for the formation of a combined electron-ion or separate electron and ion beams. A number of its characteristics and the prospects for further development of an electron-ion source for industrial use on its basis are shown.
\end{abstract}

KEY WORDS: plasma source of charged particles, electron-ion impact, electron beams, compensated ion beams 


\section{REFERENCES}

1. Alyamovsky, I.V., Electron Beams and Electron Guns, Moscow, Russia: Sovetskoe Radio Press, 1966.

2. Antonovich, D.A., Gruzdev, V.A., Zalesski, V.G., Pobol, I.L., and Soldatenko, P.N., Plasma Emission Systems for Electron- and Ion-Beam Technologies, High Temp. Mater. Process., vol. 21, no. 2, pp. 143-159, 2017.

3. Barchenko, V.T., Gruzdev, V.A., Zalesskiy, V.G., Kuzmichev, A.I., Lisenkov, A.A., Pavlenko, T.S., and Petrovich, O.N., Physics and Technology of Plasma Emission Systems, St. Petersburg, Russia: SPbGETU "LEU" Press, 2014.

4. Bogomolov, B.K., Plasma Chemical Etching of Silicon in Chlorine to Containing Plasma Used in Nanoelectronics, Proc. 10th Int. Conf. on Actual Problems of Electronic Instrument Engineering, APEIE-2010, vol. 1, pp. 23-30, 2010.

5. Bugaev, S.P., Kreindel, Yu.E., and Shchanin, P.M., Large-Section Electron Beams, Moscow, Russia: Energoizdat Press, 1984.

6. Burdovitsin, V.A., Klimov, A.S., Medovnik, A.V., Oks, E.M., and Yushkov, Yu.G., Forevacuum Plasma Electron Sources, Tomsk, Russia: Tomsk State University Press, 2014.

7. Gruzdev, V.A. and Zalesski, V.G., About the Mechanism of Occurrence of Electric Field in Plasma at Electron Emission, Herald of Polotsk State Univ., Ser. C, Fundam. Sci., no. 4, pp. 103-108, 2014a.

8. Gruzdev, V.A. and Zalesski, V.G., Electron-Optical Characteristics of the Beam Generated by Electron Plasma Sources, Elektrotekh. Elektron., vol. 49, nos. 5-6, pp. 264268, 2014b.

9. Gruzdev, V.A. and Zalesski, V.G., Emission Current Formation in Plasma Electron Emitters, J. Phys. D, Appl. Phys., vol. 5, pp. 82-90, 2009.

10. Gruzdev, V.A. and Zalesski, V.G., Emission Current Formation in Plasma Electron Emitters, Plasma Phys. Rep., vol. 13, pp. 1191-1198, 2010.

11. Gruzdev, V.A., Zalesski, V.G., Antonovich, D.A., and Golubev, Yu.P., Universal Plasma Electron Source, Vacuum, vol. 77, pp. 399-405, 2005.

12. Kreindel, Yu.E., Plasma Electron Sources, Moscow, Russia: Atomizdat Press, 1977.

13. Kuzmichev, A.I., Magnetron Sputtering Systems. Book 1. Introduction to the Physics and Technology of Magnetron Sputtering, Kiev, Ukraine: Avers Press, 2008.

14. Moskalev, B.I., Discharge with a Hollow Cathode, Moscow, Russia: Energiya Press, 1969.

15. Penning, F.M., Coating by Cathode Disintegration. US Patent 2,146,025, N.V. Philips, Eindhoven, Netherlands: Gloeilampenfabrieken, 1939.

16. Zalesski, V.G. and Antonovich, D.A., Peculiarities of Plasma Electron Sources Operation at High Pressures, J. Phys. D, Appl. Phys., vol. 40, pp. 7771-7777, 2007.

https://www.dl.begellhouse.com/journals/57d172397126f956,046b81 555aaffc76,670234064252d43e.html 